\title{
Toward a Personalized learning Path through a Services-Oriented Approach
}

\author{
https://doi.org/10.3991/ijet.v14i15.10951 \\ Mohamed Bendahmane $\left({ }^{\square}\right)$ \\ Ibn Tofail University, Kenitra, Morocco \\ med bendahmane@yahoo.fr \\ Brahim El Falaki \\ Mohammed Vth University, Rabat, Morocco \\ Mohammed Benattou \\ Ibn Tofail University, Kenitra, Morocco
}

\begin{abstract}
In most existing E-learning systems, activities' content and order are presented in a static manner without taking into consideration the learners characteristics, profiles or competencies. The challenge is to adapt and regulate learning processes according to the learner profile by applying learning models that use new information technologies. There are several adaptation approaches of E-learning environments, such as, adaptive hypermedia system, semantic web, etc. In our proposed system, we adopted a Competency Based Approach to offer each learner an individualized learning path for the acquisition of the competence targeted on the basis of the collaborative filtering. Concerning the technological aspect, the system is implemented as a web services while adhering to a service-oriented architecture. This allows interoperability with heterogeneous learning systems.
\end{abstract}

Keywords-E-Learning; Learner profile; collaborative filtering; Serviceoriented architecture

\section{$1 \quad$ Introduction}

E-Learning is a type of distance education, and is characterized by the use of new internet multimedia technologies to improve learning quality. At present, Distance Learning based on Web because of its character of flexibility, simple, reliability, compatibility have become an important mode and development way in the Distance Learning [1]. This training method has been the subject of several research studies to define standards, develop specifications, standardize and implement tools and platforms. Certainly, the use of Web technologies in education field offers new opportunities to implement new didactical intentions in new learning contexts. However, the quality of these pedagogical approaches in IT environments depends on their ability to provide learners with learning pathways tailored to their needs. As a result, the Hu- 
man Learning Computer Environments (EIAH) must manage learners differences and heterogeneity and offer them individualized pedagogical treatments.

For the implementation of the proposed system, we use the collaborative filtering algorithm to regulate the educational pathways for the competence acquisition, that leads us to consider different concepts, approaches and architectures: the learning individualization, competency-based learning, dynamic learning pathway, collaborative filtering, adaptive testing, Services oriented architecture, modeling pedagogical objects (actors and resources). The system was tested on Specialized Institute of Applied Technologies learners in Morocco.

\section{State of the Art}

The personalized e-learning system is a new distance learning method that aims to adapt learning to the learner profile. The personalization concept is based on an individualization approach of learning path to advance learner according to its rhythm, level and specificity in order to acquire a targeted skill.

Personalized learning systems was influenced by many theoretical researches in several fields like psychology, artificial intelligence, and education [2]. However, they agreed on the main elements of an personalized education system that can be summarized in : learner model, pedagogical resource model, learning model, adaptation model.

ANATOMY-TUTOR [3] for example, is an adaptive anatomy teaching system that focuses on the learner profile. This system uses an adaptation model that predefines the sequences and stereotype the knowledge.

Whereas AHA is an open Adaptive Hypermedia Architecture providing adaptive content presentation based on fragments as well as link annotation and link hiding [4]. The current version is based on AHAM (Adaptive Hypermedia Application Model) [5]. AHA uses an oriented content learning model, using fragment whose sequence will be decided at the time of a learning scenario.

ELM-ART [6] is an intelligent interactive educational system that offered a creative combination of intelligent tutoring and adaptive hypermedia technologies. It use an activities oriented learning model. ELM-ART provides adaptive navigation support, course sequencing, individualized diagnosis of student solutions, and examplebased problem-solving support. It use an activities oriented learning model also.

Another learning model VARK adopted by other educational systems mainly involves the perception form preferred for learning, that is, whether it is delivered by visual perception, or auditory perception, or other perception modes [7].

The WELSA as a network education system with learning style adaptability integrates several features of models proposed by other scholars to build an instructional system of unified learning model adaptable to the course learners [8].

ALFANET [9] (Active Learning For Adaptive Internet) was developed within a European project from May 2002 to April 2005. It uses a service-oriented architecture, multi-agent technology and is based on IMS-LIP learner model technology. 
"MATHEMA" is A Learner-controlled Adaptive Educational Hypermedia System. The educational purpose of the AEHS MATHEMA is to support senior high school students or novices of higher education, through an interactive and constructivist educational material, in learning Physics individually and/or collaboratively [10].

AMDPC (Adaptation with Multidimensional Customization Criteria) is an adaptive learning system for the field of computer networks. It focuses on customizing content and user interface, based on the Felder-Silverman learning style model and Witkin's cognitive style model. [11].

LS-AEHS (learning style based on the adaptive online learning hypermedia system) is an adaptive hypermedia system that teaches chemistry taking into consideration the learner's learning style. It is a system focused on adapting content to learning styles [12].

TANGOW (Task-based Adaptive learNer Guidance On the Web) adapts dynamically the course structure and sequencing to the student's profile based on ILS (Index of Learning Styles) questionnaire developed by Felder and Soloman[13].

INSPIRE (INtelligent System for Personalized Instruction in a Remote Environment) is an Adaptive Educational Hypermedia System that supports several levels of adaptation: from full system-control to full learner-control, and offers learners the option to decide on the level of adaptation of the system by intervening in different stages of the lesson generation process and formulating the lesson contents and presentation[14].

At present, for the purpose of enhancing the teaching system of personalized distance learning, there is a popular foreign student model based on Bayesian network.

According to each student's evidence of the individualized distance learning system in the learning process, reasoning and predicting each student's next operation are performed[15].

A comparative study of the different learning systems in Table 1 revealed that the majority of adaptive systems have agreed on the main elements of an adaptive education system which are the learner model, the pedagogical resource model, the learning model and the adaptation model. We also found that the so-called "intelligent" systems are focusing on learning methods despite of the learner model. On the other hand, the hypermedia systems are based on resources model and learners' profiles without taking account of the learning processes.

Table 1. Adaptative and intelligent learning systems

\begin{tabular}{|c|c|c|c|c|c|c|c|}
\hline & \multicolumn{2}{|c|}{ Learner Model } & \multirow{2}{*}{$\begin{array}{c}\text { Resources } \\
\text { Model }\end{array}$} & \multirow{2}{*}{\begin{tabular}{|c|} 
Learning \\
Model
\end{tabular}} & \multicolumn{3}{|c|}{ Adaptation } \\
\hline & contents & Refresh & & & Type & Technical aspect & scope \\
\hline AEHS-LS & $\begin{array}{l}\text { Profile, level } \\
\text { of } \\
\text { knowledge } \\
\end{array}$ & $\begin{array}{l}\text { dynamical- } \\
\text { ly by the } \\
\text { syste }\end{array}$ & $\begin{array}{l}\text { Domain } \\
\text { model }\end{array}$ & $\begin{array}{l}\text { Oriented } \\
\text { content }\end{array}$ & $\begin{array}{l}\text { Presentation } \\
\text { and navigation }\end{array}$ & $\begin{array}{l}\text { Rules of meth- } \\
\text { ods' selection }\end{array}$ & contents \\
\hline AHA 3.0 & $\begin{array}{l}\text { Profile, level } \\
\text { of } \\
\text { knowledge }\end{array}$ & $\begin{array}{l}\text { dynamical- } \\
\text { ly by the } \\
\text { system }\end{array}$ & $\begin{array}{l}\text { Domain } \\
\text { model }\end{array}$ & \begin{tabular}{|l|} 
Oriented \\
content \\
using \\
fragments \\
\end{tabular} & $\begin{array}{l}\text { Presentation } \\
\text { and navigation }\end{array}$ & $\begin{array}{l}\text { Link annotation, } \\
\text { link hiding using } \\
\text { user model } \\
\text { values }\end{array}$ & contents \\
\hline ALFANET & $\begin{array}{l}\text { Level of } \\
\text { knowledge }\end{array}$ & static & \begin{tabular}{|l|} 
IMS-QTI, \\
IEEE- \\
LOM
\end{tabular} & $\begin{array}{l}\text { Oriented } \\
\text { activities }\end{array}$ & $\begin{array}{l}\text { Contents, } \\
\text { Presentation }\end{array}$ & $\begin{array}{l}\text { Feedback to } \\
\text { author + learning } \\
\text { paths for user }\end{array}$ & $\begin{array}{l}\text { Learning } \\
\text { paths }\end{array}$ \\
\hline
\end{tabular}




\begin{tabular}{|c|c|c|c|c|c|c|c|}
\hline & & & & & & profiles & \\
\hline AMDPC & $\begin{array}{l}\text { Profile, level } \\
\text { of } \\
\text { knowledge }\end{array}$ & $\begin{array}{l}\text { dynamical- } \\
\text { ly by the } \\
\text { system }\end{array}$ & $\begin{array}{l}\text { Domain } \\
\text { model }\end{array}$ & $\begin{array}{l}\text { Oriented } \\
\text { content }\end{array}$ & $\begin{array}{l}\text { Presentation } \\
\text { and navigation }\end{array}$ & $\begin{array}{l}\text { Rules of learning } \\
\text { unit selection }\end{array}$ & $\begin{array}{l}\text { Learning } \\
\text { paths }\end{array}$ \\
\hline $\begin{array}{l}\text { ANATOM- } \\
\text { TUTOR }\end{array}$ & Profile & $\begin{array}{l}\text { dynamical- } \\
\text { ly by the } \\
\text { system }\end{array}$ & $\begin{array}{l}\text { Domain } \\
\text { model }\end{array}$ & $\begin{array}{l}\text { Oriented } \\
\text { activities }\end{array}$ & $\begin{array}{l}\text { Navigation, } \\
\text { presentation }\end{array}$ & $\begin{array}{l}\text { Predefined } \\
\text { sequence and } \\
\text { stereotype } \\
\text { knowledge } \\
\end{array}$ & $\begin{array}{l}\text { Test } \\
\text { activities }\end{array}$ \\
\hline ELM-ART & $\begin{array}{l}\text { Prerequisite, } \\
\text { level of } \\
\text { knowledge }\end{array}$ & static & $\begin{array}{l}\text { Domain } \\
\text { model }\end{array}$ & $\begin{array}{l}\text { Oriented } \\
\text { activities }\end{array}$ & navigation & $\begin{array}{l}\text { Rules of meth- } \\
\text { ods' selection }\end{array}$ & contents \\
\hline INSPIRE & $\begin{array}{l}\text { Profile, level } \\
\text { of } \\
\text { knowledge }\end{array}$ & dynamic & metadata & $\begin{array}{l}\text { Oriented } \\
\text { activities }\end{array}$ & navigation & $\begin{array}{l}\text { Rules of meth- } \\
\text { ods' selection }\end{array}$ & $\begin{array}{l}\text { Learning } \\
\text { paths }\end{array}$ \\
\hline iWEAVER & $\begin{array}{l}\text { Level of } \\
\text { knowledge }\end{array}$ & dynamic & $\begin{array}{l}\text { Domain } \\
\text { model }\end{array}$ & $\begin{array}{l}\text { Oriented } \\
\text { content }\end{array}$ & navigation & $\begin{array}{l}\text { Link annotation, } \\
\text { link hiding using } \\
\text { user model } \\
\text { values }\end{array}$ & $\begin{array}{l}\text { Learning } \\
\text { paths }\end{array}$ \\
\hline LS-AEHS & \begin{tabular}{|l|} 
Profile, level \\
of \\
knowledge
\end{tabular} & dynamic & $\begin{array}{l}\text { Domain } \\
\text { model }\end{array}$ & $\begin{array}{l}\text { Oriented } \\
\text { content }\end{array}$ & navigation & $\begin{array}{l}\text { Rules of meth- } \\
\text { ods' selection }\end{array}$ & contents \\
\hline MATHEMA & $\begin{array}{l}\text { level of } \\
\text { knowledge }\end{array}$ & dynamic & metadata & $\begin{array}{l}\text { Oriented } \\
\text { content }\end{array}$ & $\begin{array}{l}\text { Presentation } \\
\text { and navigation }\end{array}$ & $\begin{array}{l}\text { Predefined } \\
\text { sequence, } \\
\text { Feedback to } \\
\text { author } \\
\end{array}$ & contents \\
\hline METADYNE & $\begin{array}{l}\text { Objectives, } \\
\text { level of } \\
\text { knowledge, } \\
\text { profile }\end{array}$ & dynamic & $\begin{array}{l}\text { Domain } \\
\text { model }\end{array}$ & $\begin{array}{l}\text { Resources } \\
\text { oriented }\end{array}$ & $\begin{array}{l}\text { Navigation, } \\
\text { presentation }\end{array}$ & $\begin{array}{l}\text { Rules of learning } \\
\text { unit selection }\end{array}$ & contents \\
\hline OSCAR CITS & $\begin{array}{l}\text { Profile, level } \\
\text { of } \\
\text { knowledge }\end{array}$ & $\begin{array}{l}\text { dynamical- } \\
\text { ly by the } \\
\text { system }\end{array}$ & $\begin{array}{l}\text { Domain } \\
\text { model }\end{array}$ & $\begin{array}{l}\text { Oriented } \\
\text { activities }\end{array}$ & $\begin{array}{l}\text { Presentation } \\
\text { and navigation }\end{array}$ & $\begin{array}{l}\text { Rules of learning } \\
\text { unit selection }\end{array}$ & $\begin{array}{l}\text { Learning } \\
\text { paths }\end{array}$ \\
\hline PROTUS 2.0 & $\begin{array}{l}\text { Profile, level } \\
\text { of } \\
\text { knowledge }\end{array}$ & $\begin{array}{l}\text { dynamical- } \\
\text { ly by the } \\
\text { system }\end{array}$ & $\begin{array}{l}\text { Domain } \\
\text { model }\end{array}$ & $\begin{array}{l}\text { Oriented } \\
\text { activities }\end{array}$ & $\begin{array}{l}\text { Presentation } \\
\text { and navigation }\end{array}$ & $\begin{array}{l}\text { Rules of learning } \\
\text { unit selection }\end{array}$ & $\begin{array}{l}\text { Learning } \\
\text { paths }\end{array}$ \\
\hline TANGOW & $\begin{array}{l}\text { Objectives, } \\
\text { level of } \\
\text { knowledge, } \\
\text { profile }\end{array}$ & dynamic & $\begin{array}{l}\text { Domain } \\
\text { model }\end{array}$ & $\begin{array}{l}\text { Oriented } \\
\text { content }\end{array}$ & $\begin{array}{l}\text { Presentation } \\
\text { and navigation }\end{array}$ & $\begin{array}{l}\text { Predefined } \\
\text { sequence and } \\
\text { stereotype } \\
\text { knowledge }\end{array}$ & contents \\
\hline WELSA & profile & dynamic & $\begin{array}{l}\text { Domain } \\
\text { model }\end{array}$ & \begin{tabular}{|l|} 
Resources \\
oriented
\end{tabular} & $\begin{array}{l}\text { Navigation, } \\
\text { presentation }\end{array}$ & $\begin{array}{l}\text { Rules of learning } \\
\text { unit selection }\end{array}$ & contents \\
\hline
\end{tabular}

\section{$3 \quad$ Learner and Competency Modeling}

In each learning system, online or face-to-face, adaptive or standard, the teacher goal is to be able to transmit a know-how to the learners. In the competency-based approach, this know-how is represented by a competency to be acquired. When it comes to an adaptive system, the goal is to be able to adapt the learning path to learner characteristics in order to eventually acquire the desired competencies. Three key words stand out in the adaptation process: learner, competence, teacher(Fig 1). We 
therefore find it wise to start designing our approach by respecting the norms and standards by modeling learner and competency.

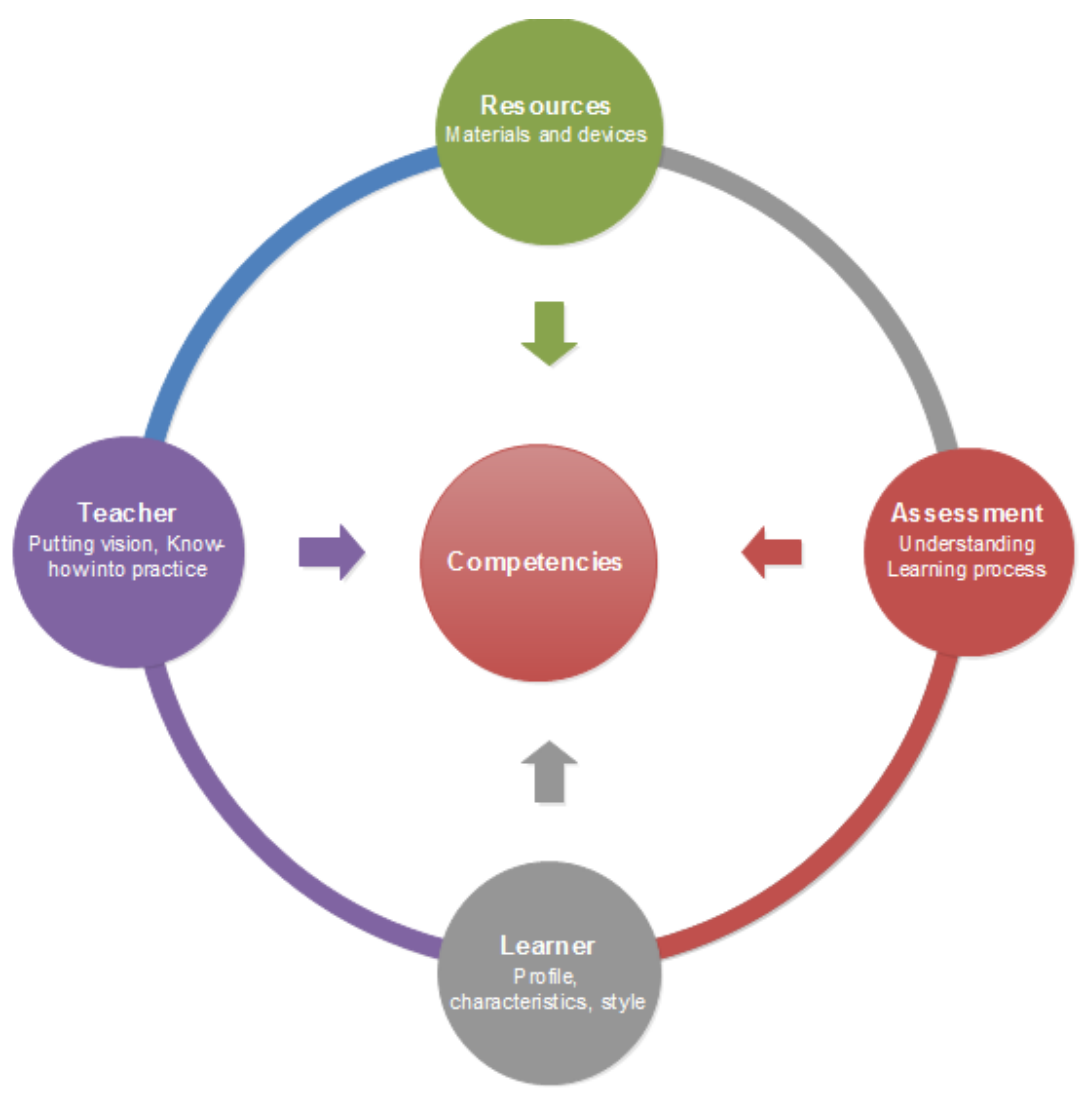

Fig. 1. Learning system components

The first phase of our work was to model our system according to IMS-LD, this is done by modeling learner and competency. The adoption of IMS LD is justified by its ability to integrate the notion of activity and the ability to support the development of theories and pedagogical approaches. Fig.2 presents a comparative study of standards LOM, SCORM and IMS LD. 


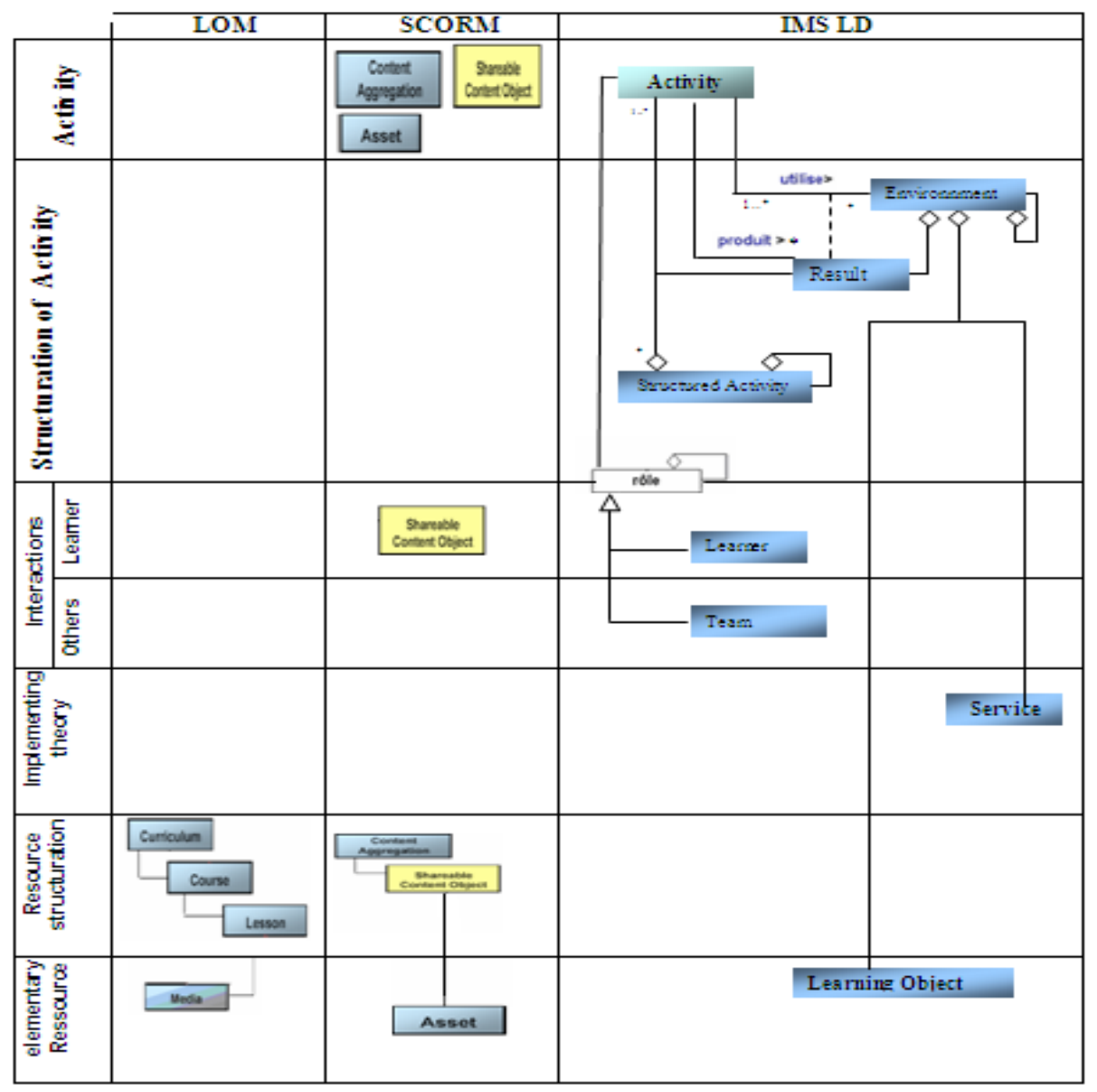

Fig. 2. Comparative study of standards

\subsection{Learner modeling}

Learning path personalization process is based on the learner identification, his/her ability, prior knowledge and current performance for the acquisition of competencies. Thus, learner's feature recognition is the first phase of adaptive learning, called the modeling of learners.

In an Competence Based Approach(CBA), learner modeling is a competencies state representation. It should characterize learner static (profile) and dynamic (progress) information. In our proposed system, we adopt the IMS-LIP specifications. IMS LIP (Learner Information Package) is defined in a XML structure (Fig.3) for the exchange of data between systems learners including learning management systems[17]. IMS LIP model defines a structure of user data into eleven categories are: Identification, Accessibility, QCL, Activity, Goal, Competency, Interest, Transcript, Affiliation, Security Key, and Relationship. 


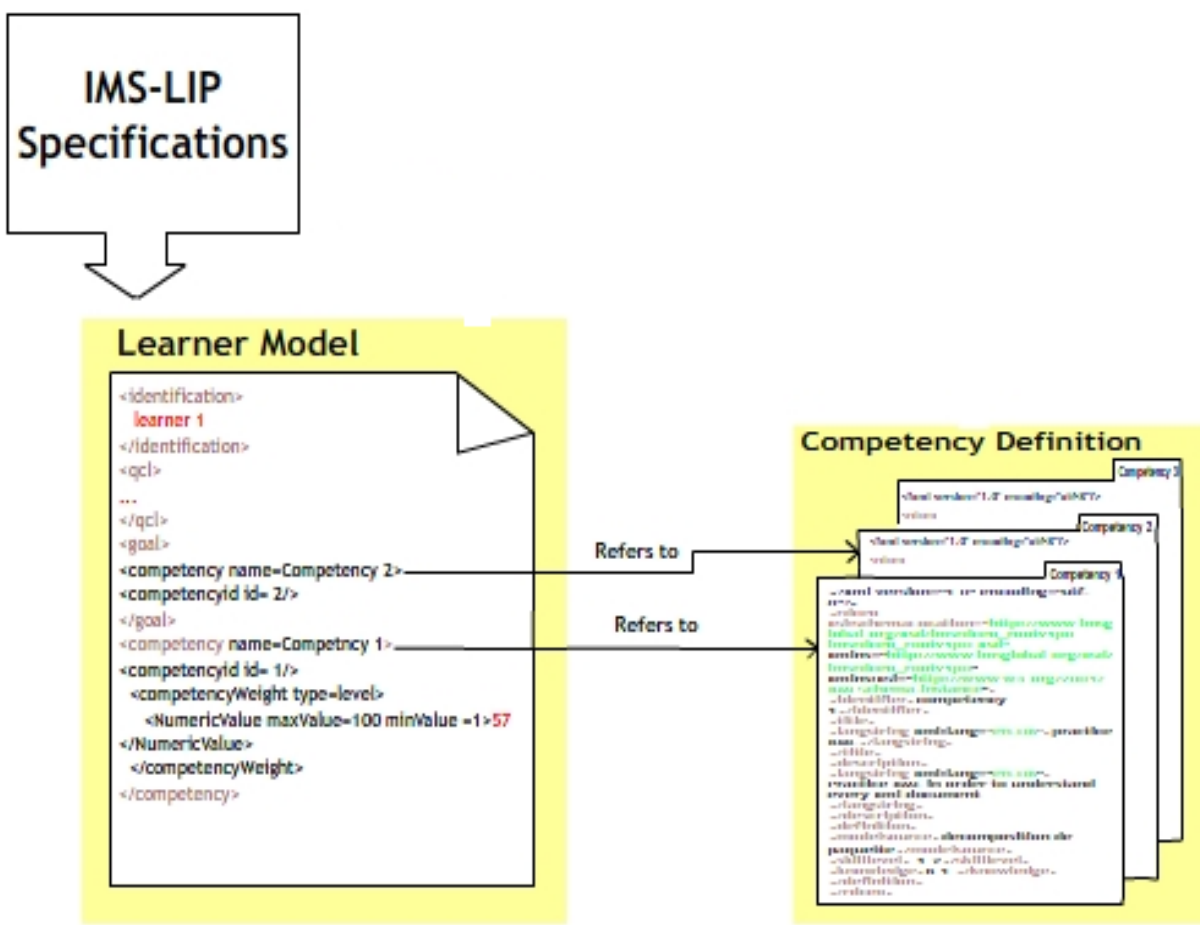

Fig. 3. Learner model using competency definition [16]

\subsection{Competency modeling}

The use of competency-based approach requires competency modeling. To model the competence in our approach, we opted for the IMS RDCEO standard: IMS Reusable Definition of Competence or Educational Objective.

\subsection{Learning object evaluation modeling}

In our approach, the teacher is responsible for organizing the course in chapters containing a set of knowledge to acquire which we have named learning objects(LO). Each LO will be the subject of an evaluation proposed as part of an educational scenario. This uses a bank of evaluation items described in a formal and standard way. In our system, we opt for the IMS-QTI standard, which allows representing the data structure of a question and a test and their corresponding results. To provide interoperability, it was wise to use an XML file. 


\section{The Proposed Approach}

\subsection{System actors}

The goal of our approach is to be able to choose a learning path adapted to each learner. This personalization will be done according to parameters such as learner learning style, understanding degree, as well as the difficulty of course topics, and course learning materials.

For this we have identified three actors for our system: Teacher, learner and the administrator.

The teacher roles are :

- Define the didactic strategy,

- Prepare the course by distinguishing the objectives to be achieved,

- Decompose the course into learning objects(LO),

- Define a difficulty level for each learning object,

- Develop an evaluation post-test for each LO and possibly a minimum score to have to validate the $\mathrm{LO}$,

- Prepare the initial Cognitive State Test (CST) for evaluating the starting knowledge of the learner, that is the knowledge already possessed by the learner with respect to the topic to be learned. The results of these tests will implement our domain model and will be stored in the global database.

The administrator role is to manage the various tests and questionnaires, to consult the profiles, manage the domain and learner model, and to administer the database by creating the accounts, the privileges, the rights of access...etc.

On the other hand, the learner will be able to :

- Pass a questionnaire to determine his learning style

- Choose a topic and pass a pre-test

- study the learning object recommended by the system and pass its evaluation

In this work we address the problem of helping learner during his learning activity by taking into consideration his cognitive state, his learning style and the teacher's learning strategy.

To do this, we must first define the learning style of each learner. A learning style is defined as a characteristic of cognitive, affective, and psychological behavior that serves as a relatively stable indicator of how a learner perceives, interacts with, and responds to the learning environment [17]. Most known learning style models are Myers-Briggs model, Kolb model [18, 19, 20], Honey-Mumford model [19], FelderSilverman model [19,21,22], Grasha-Riechman model. Table 2 represents some known Learning styles models. 
Table 2. Some known Learning styles models.

\begin{tabular}{|l|l|}
\hline \multicolumn{1}{|c|}{ Learning style model } & \multicolumn{1}{c|}{ Dimensions within the model } \\
\hline Kolb model & $\begin{array}{l}\text { Converger/Diverger } \\
\text { Assimilator/Accommodator }\end{array}$ \\
\hline Honey-Mumford model & $\begin{array}{l}\text { Activist/Reflector } \\
\text { Theorist/Pragmatist }\end{array}$ \\
\hline Felder-Silverman model & $\begin{array}{l}\text { Sensory/Intuitive Visual/Verbal Inductive/Deductive Ac- } \\
\text { tive/Reflective Sequential/Global }\end{array}$ \\
\hline Grasha-Riechman model & $\begin{array}{l}\text { Competitive/Collaborative Avoidant/Participant Depend- } \\
\text { ent/Independent }\end{array}$ \\
\hline Myers-Briggs model & $\begin{array}{l}\text { Extravert/Introvert Intuitive/Sensing Feeling/Thinking Judg- } \\
\text { ing/Perceiving }\end{array}$ \\
\hline
\end{tabular}

Our choice was therefore focused on the Felder-Silverman model (FSLSM) [21] because it is based on tendencies, asserting that learners with a high preference for certain behaviors may also act sometimes differently [23]. The Felder-Silverman model offers a questionnaire on the Learning Styles Index (ILSQ) with 44 questions divided into four sets of 11 questions to evaluate preferences [24]. Each set of questions defines one dimension of learner's cognitive model, which is thus made up of four dimensions according to Felder (Table 3). The questions are provide four values, between +11 and $-11[25]$, representing the learner's learning style preferences of each dimension.

Table 3. Learning Style Dimensions.

\begin{tabular}{|l|l|l|l|}
\hline \multicolumn{1}{|c|}{ Dimension } & \multicolumn{2}{|c|}{ Learning style } & \multicolumn{1}{c|}{ ILS sets of Questions } \\
\hline processing & Active & Reflective & Q1,Q5,Q9,Q13,Q17,Q21,Q25,Q29,Q33,Q37,Q41 \\
\hline perception & sensing & intuitive & $\begin{array}{l}\text { Q2,Q6, Q10, Q14,Q18, Q22,Q26, Q30,Q34, Q38, } \\
\text { Q42 }\end{array}$ \\
\hline Reception & Visual & Verbal & $\begin{array}{l}\text { Q3,Q7, Q11, Q15,Q19, Q23, Q27, Q31,Q35, Q39, } \\
\text { Q43 }\end{array}$ \\
\hline Understanding & Sequential & Global & $\begin{array}{l}\text { Q4,Q8, Q12, Q16,Q20, Q24,Q28, Q32,Q36, Q40, } \\
\text { Q44 }\end{array}$ \\
\hline
\end{tabular}

\subsection{System architecture}

The use of a Service-Oriented Architecture (SOA) seemed wise to implement our approach. The goal is to decompose the functionality of our system on components, each component will be developed as a web service.

This architecture is based on service discovery concept and dynamic link. A service provider discovers this one in a directory according to the criteria expressed during the execution. the principles of SOA are :

- Services autonomy : services manage their functionality and are self catering

- Services statelessness : services have no state, either they return the desired result or an exception 
- Abstraction of services : the consumer of the service sees it as a black box, its logic is concealed

- Services discoverability : the services are published in XML-based service books known as Universal Description Discovery and Integration (UDDI) for their discovery and consumption.

- Services normalization : Services are decomposed or consolidated (normalized) to minimize redundancy. In some, this may not be done, These are the cases where performance optimization, access, and aggregation are required.[26]

- Composability of services : the services can be used to compose other services.

By opting for this architecture we wanted to ensure:

- Interoperability: thus having a system independent of the different platforms and environments.

- Reusability of services.

The figure 5 presents the principles of services oriented architecture

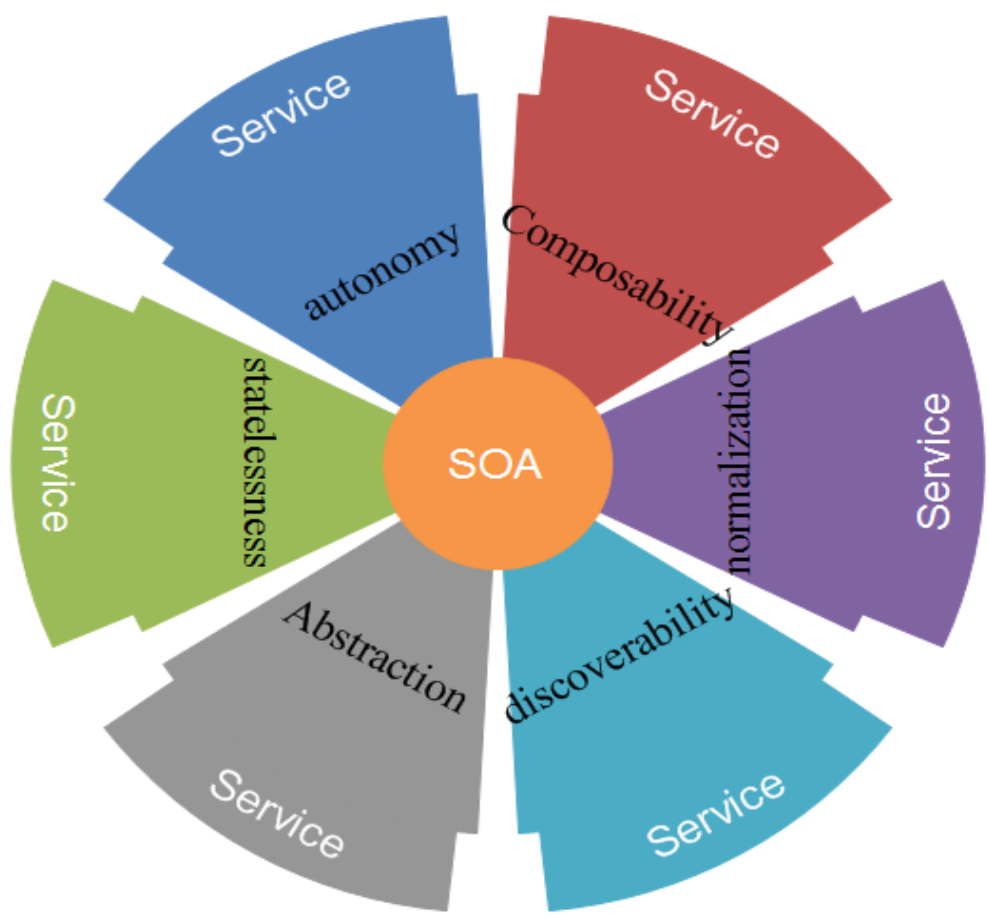

Fig. 4. The principles of service-oriented architecture

We propose three orchestrated components in a SOA. These services are responsible for collection, analysis, adaptation, prediction and regulation of leaning objects (LO) to personalize learning path.

Figure 6 shows the various stages of the proposed approach. 


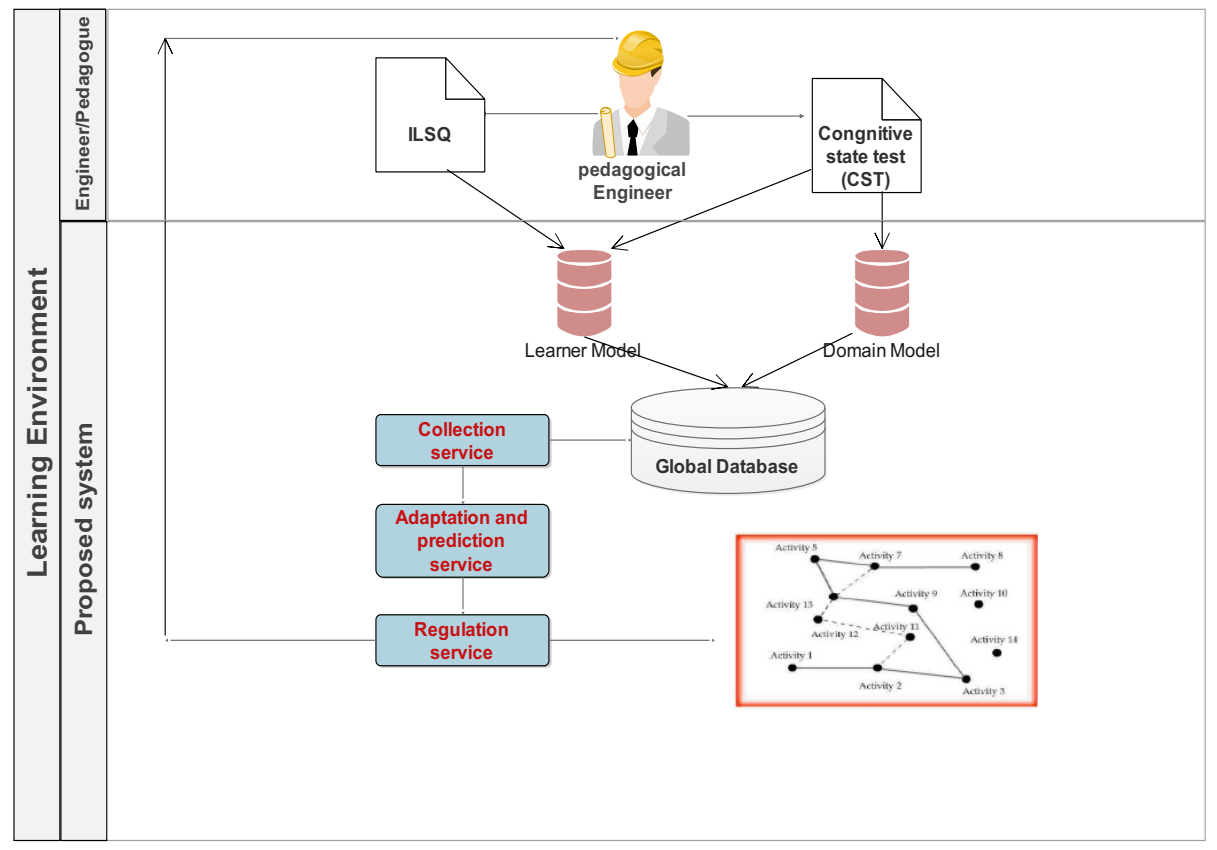

Fig. 5. The proposed System Architecture

By following the principles of SOA, we have decomposed our system into three services :

- Collection service

- Adaptation and prediction service

- Regulation service

Collection service: is a web service that collects data from the database using SQL language. It should be noted that this database will be populated by three categories of information:

- The Learners basic information : Last name, first name, age, sex, ... etc.

- Learner style: knowing that each learner will pass the Learning Style Questionnaire(ILSQ ) proposed by Felder-Silverman Model [27] to determine learner preferences and style.

- The learner initial knowledge and prerequisites for each learning object (LO). Thus, each learner will pass a cognitive state test (CST) concerning the subject to learn.

Adaptation and prediction service: The adaptation and prediction service is a web service used to classify learners and give predictions for learning objects. The idea is to find other learners whose past ratings for learning objects are similar for the active learner and use their ratings to predict current learner's preference for a learn- 
ing object he/she has not rated. For that, we opted for the K-NN algorithm, which is the most popular method used for classification, estimate, and prediction [28].

The measurement for the weight for similarity between two learners $\mathrm{u}, \mathrm{v}$ is the Pearson correlation coefficient [29].

$$
w(u, v)=\frac{\sum_{j}^{m}\left(r_{u, j}-\bar{r}_{u}\right)\left(r_{v, j}-\bar{r}_{v}\right)}{\sqrt{\sum_{j}^{m}\left(r_{u, j}-\bar{r}_{u}\right)^{2}} \sqrt{\sum_{j}^{m}\left(r_{v, j}-\bar{r}_{v}\right)^{2}}}
$$

where :

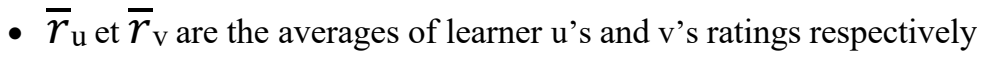

- $r_{u, j}$ and $r_{V, j}$ are learner u's ratings and learner v's ratings for the learning object $j$.

If the learner $u$ and $v$ have a similar rating for a LO, $w(u, v)$ will be positive, else $w(u, v)$ will be negative.

The prediction step consist to generate predictions for current learner $u$ on learning object j. For that, K-NN uses similarity to select $\mathrm{N}$ neighbors of $\mathrm{u}$. Once $\mathrm{N}$ has been selected, the recommender system combines the $\mathrm{N}$ learners ratings to generate prediction for learner u's preference for a learning object $\mathrm{j}$ :

$$
P_{u, j}=\bar{r}_{u}+\frac{\sum_{v=1}^{n} w(u, v)\left(r_{v, j}-\bar{r}_{v}\right)}{\sum_{v=1}^{n}|w(u, v)|}
$$

This prediction respects the algorithm 1

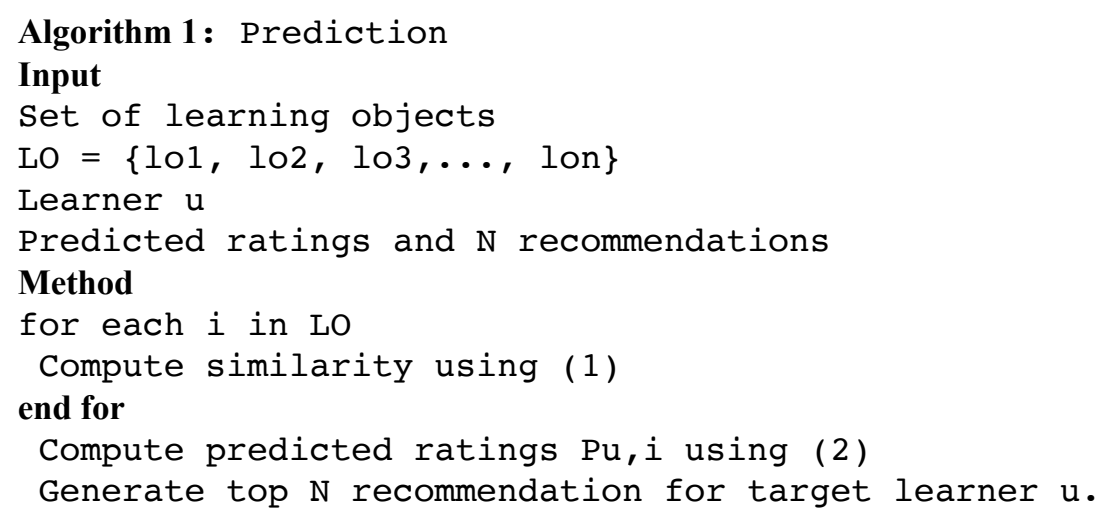

The regulation service: Offers the learner the LO predicted by the adaptation service (which has the highest value $P u, L O$ of equation 2 . After having studied the predicted LO, the learner passes the LO post-test and gets a score. The result of the latter will update the learner model.

To model the business process of our system (Fig. 7) we have opted for the Business Process Modeling Notation(BPMN). The BPMN is a standard that has emerged by proposing a set of standardized graphical elements and a grammar for their manip- 
ulation. It defines a business process diagram (BPD), which is based on a technique suitable for creating graphical models of business process operations.

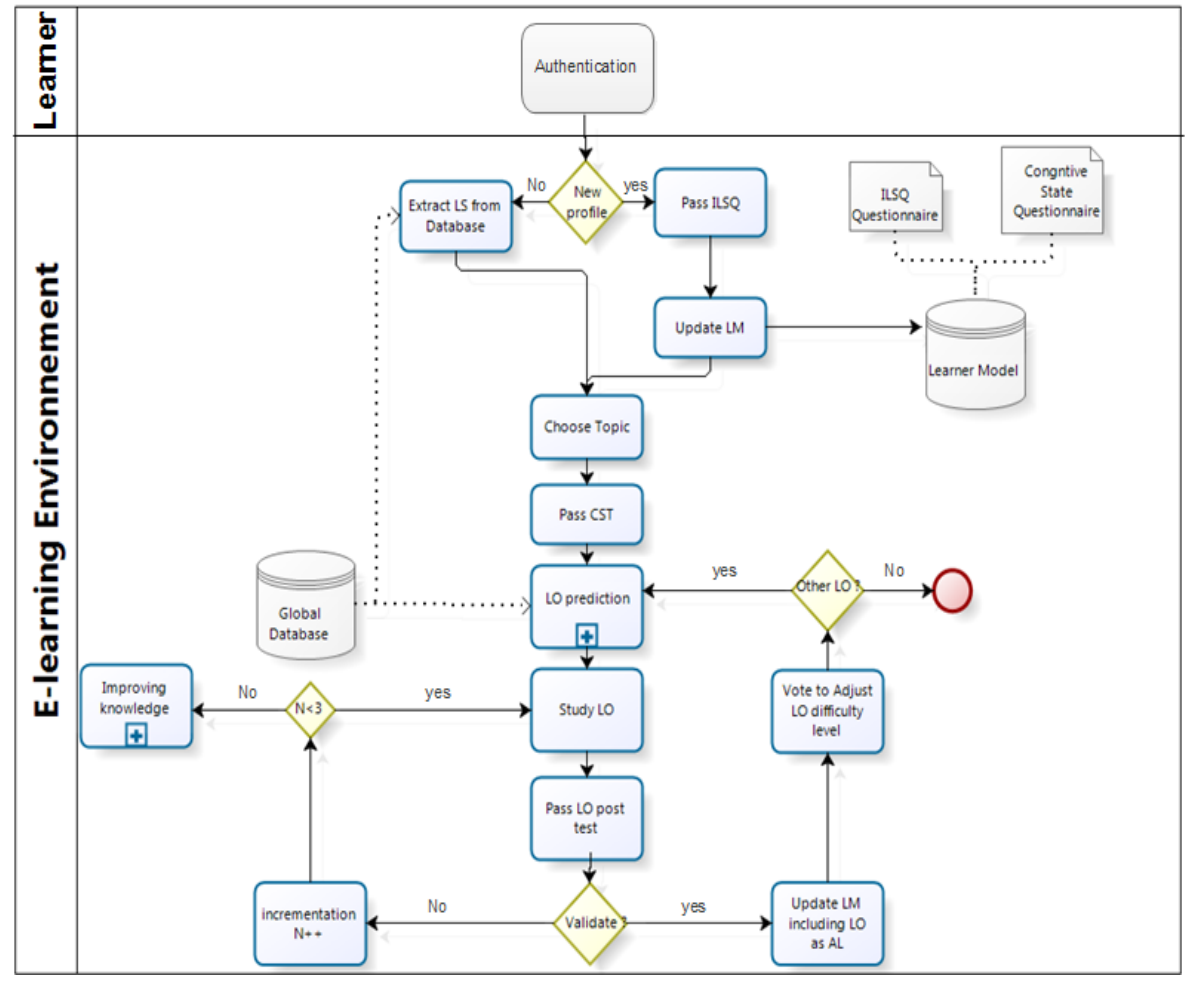

Fig. 6. Business process diagram representing our system

\section{Conclusions}

Issues relating to the adaptation or individualization of the learning path and focusing on the learner profile have been widely discussed in recent years. Our proposal is different, it is based on web services' independence and reusability to implement components that are responsible for collection, prediction and regulation of learning objects. In this article, we propose a personalized e-Learning model that respects a service-oriented architecture, which takes into account learner characteristics and profile and uses a collaborative filtering method for the prediction system. For the design of our system we opted for the standard IMS Learning.

In the future work, the algorithm model will be implemented in detail, and the theory will be implemented in available systems to meet the actual demands the majority of learners. 


\section{References}

[1] Lan-zhong Wang. Personalized Teaching Platform Based on Web Data Mining. International Journal of Emerging Technologies in Learning, 11(11): 15-20. https://doi.org/10. 3991/ijet.v11i11.6253

[2] D. Schneider, "Conception and implementation of rich pedagogical scenarios through collaborative portal sites, working pape", Future of Learning Workshop, Sevilla 2003. https://doi.org/10.1007/bf01142356

[3] I. Beaumont. User modeling in the interactive anatomy tutoring system ANATOMTUTOR. In User Models and User Adapted Interaction, 4(1), pages 21-45, 1994.

[4] P. De Bra and L. Calvi. AHA! An open Adaptive Hypermedia Architecture. In The New Review of Hypermedia and Multimedia, 4, pages 115-139, Taylor Graham Publishers, 1998. http://aha.win.tue.nl/ https://doi.org/10.1080/13614569808914698

[5] P. De Bra and A. Aerts and D. Smits and N. Stash. AHA! meets AHAM. In Proceedings of the Second International Conference on Adaptive Hypermedia and Adaptive Web-Based Systems, pages 381-384, Springer LNCS 2347, May 2002. https://doi.org/10.1007/3-540$\underline{47952-x \quad 44}$

[6] G. Weber and P. Brusilovsky ELM-ART: An Adaptive Versatile System for Webbased Instruction. In International Journal of Artificial Intelligence in Education, 12, pages 351384, 2001.

[7] I. J. Prithishkumar, S. A. Michael. Understanding your student: using the VARK model. Journal of postgraduate medicine, 60(2), 183- 186. 2014. https://doi.org/10.4103/00223859.132337

[8] E. Popescu, P. Trigano, C. Badica, B. Butoi, M. Duica. A course authoring tool for WELSA adaptive educational system. Proc. ICCC 2008, 531-534. 2008

[9] O. C. Santos, J. G. Boticario and C. Barrera. The Standards-based Architecture of the Adaptive Learning Environment aLFanet. In WSEAS Transactions on Computers, 3, pages 1814-1818, December 2004. http://rtd.softwareag.es/alfanet

[10] Papadimitriou, A., Grigoriadou, M., \& Gyftodimos, G. "MATHEMA: A Learnercontrolled Adaptive Educational Hypermedia System". Journal of Information Technology and Application in Education, 1(2), 47-73, 2012

[11] Yang, T. C., Hwang, G. J., \& Yang, S. J. H. "Development of an adaptive learning system with multiple perspectives based on students' learning styles and cognitive styles". Journal of Educational Technology \& Society, 16(4), 185-200, 2013

[12] Drissi, Samia, and Abdelkrim Amirat. "An adaptive e-learning hypermedia system: Design and evaluation." 2013 3rd International Symposium ISKO-Maghreb, 2013. https://doi.org/10.1109/ISKO-Maghreb.2013.6728106

[13] Paredes, P., and P. Rodriguez. "A Mixed Approach to Modelling Learning Styles in Adaptive Educational Hypermedia." Advanced Technology for Learning 1, no. 4 (2004). https://doi.org/10.2316/Journal.208.2004.4.208-0823

[14] Papanikolaou, K. A., Grigoriadou, M., Kornilakis, H., \& Magoulas, G. D. "Personalizing the Interaction in a Web-based Educational Hypermedia System: the case of INSPIRE". User modeling and user-adapted interaction, 13(3), 213-267, 2003 https://doi.org/10.1023/A:1024746731130

[15] Zhimin Qi. Personalized Distance Education System Based on Data Mining. International Journal of Emerging Technologies in Learning, 13(7): 4-16. https://doi.org/10.3991/ijet.v13i07.8810

[16] CEN/ISSS cwa 15455, "A European Model for Learner Competencies", ICS 03.180; 35.240.99, (November 2005)

[17] Felder R., Brent R., 2005, "Understanding Student Differences", Journal of Engineering Education., Vol 94(1), pp. 57-72. https://doi.org/10.1002/j.2168-9830.2005.tb00829.x 
[18] Liu Y., Ginther D., "Cognitive Styles and Distance Education", Online Journal of Distance Learning Administration., Vol 2(3), pp. 1-19. 1999

[19] Sleigh J., , "Learning Styles - from Theory to Practice. Training and Development in Australia", Australian Institute of Training and Development., 29(2), p. 44. 2002

[20] Wikipedia. "Learning Styles", from: http://en.wikipedia.org/wiki/Learning_style (last visited on 23.06.2017).

[21] Graf S., Viola S., Kinshuk T. L, "Representative Characteristics of Felder-Silverman Learning Styles: an Empirical Model", Proceedings of the IADIS International Conference on Cognition and Exploratory Learning in Digital Age. pp. 235-242. ., 2006

[22] Tinkham A. and Kamer C., "Learning Styles and Exploratory Testing", Proceedings of the Pacific Northwest Software Quality Conference. ., 2003

[23] Graf S., Kinshuk, Liu T.C., "Identifying Learning Styles in Learning Management Systems by Using Indications from Students' Behaviour". https://doi.org/10.1109/icalt.2008.84

[24] Felder, R.; and Soloman, B., "Index of learning styles questionnaire", 2007 https://www.webtools.ncsu.edu/learningstyles/

[25] Felder, R. M., \& Spurlin, J. Applications, reliability and validity of the index of learning styles. International journal of engineering education, 21(1), 103-112. 2005

[26] Tony Shan ,2004. "Building a service-oriented e Banking platform". IEEE International Conference on Services Computing, 2004. (SCC 2004). Proceedings. 2004. pp. 237244. https://doi.org/10.1109/scc.2004.1358011. ISBN 0-7695-2225-4.2004

[27] Felder, R.; and Soloman, B., , "Index of learning styles questionnaire", 2007, from https://www.webtools.ncsu.edu/learningstyles/

[28] Daniel, T.L., "Discovering knowledge in data: An introduction to data mining", John Wiley \& Sons, 2005

[29] X. Su, T.M. Khoshgoftaar, "A Survey of collaborative filtering techniques", Advances in Artificial Intelligence, 2009. https://doi.org/10.1155/2009/421425

\section{Authors}

Mohamed Bendahmane received a diploma of advanced graduate (DESA) in computer science, telecommunication and multimedia(ITM) from university of Mohammed-V Rabat in 2005. He is currently a PhD student in LASTID laboratory at faculty of sciences in Ibn Tofail University; and former with the Moroccan Office of professional education. His research interests are e-learning, learner path, learner model.

Brahim El Falaki Engineer degree in Computer Science in 2002; member of IEEE education and computer science; former with the Moroccan Office of professional education; 8 recent publications papers between 2009 and 2012; Ongoing research interests: Web services, e-learning and assessment. He is currently working in the Computer Science Department at Mohammadia Engineering School, Mohammed Vth University

Mohammed Benattou is a member of the IEEE and the IEEE Computer Society. Professor in faculty of sciences in Ibn Tofail University and member of LASTID laboratory at faculty of sciences in Ibn Tofail University.

Article submitted 2019-05-30. Resubmitted 2019-06-04. Final acceptance 2019-06-07. Final version published as submitted by the authors 